\title{
Author Correction: Airway response to respiratory syncytial virus has incidental antibacterial effects
}

\author{
Charles J. Sande (10 1,2,6, James M. Njunge (10 1,6, Joyce Mwongeli Ngoi ${ }^{1}$, Martin N. Mutunga ${ }^{1}$, Timothy Chege ${ }^{1}$, \\ Elijah T. Gicheru', Elizabeth M. Gardiner ${ }^{1}$, Agnes Gwela1, Christopher A. Green², Simon B. Drysdale ${ }^{2}$, \\ James A. Berkley (iD 1,3,4, D. James Nokes (iD ${ }^{1,5}$ \& Andrew J. Pollard ${ }^{2}$
}

Correction to: Nature Communications https://doi.org/10.1038/s41467-019-10222-z, published online 17 May 2019.

The original version of this Article contained an error in the spelling of the author D. James Nokes, which was incorrectly given as James Nokes. This has now been corrected in both the PDF and HTML versions of the Article.

Published online: 18 July 2019

\begin{abstract}
(c) Open Access This article is licensed under a Creative Commons Attribution 4.0 International License, which permits use, sharing, adaptation, distribution and reproduction in any medium or format, as long as you give appropriate credit to the original author(s) and the source, provide a link to the Creative Commons license, and indicate if changes were made. The images or other third party material in this article are included in the article's Creative Commons license, unless indicated otherwise in a credit line to the material. If material is not included in the article's Creative Commons license and your intended use is not permitted by statutory regulation or exceeds the permitted use, you will need to obtain permission directly from the copyright holder. To view a copy of this license, visit http://creativecommons.org/licenses/by/4.0/.
\end{abstract}

(C) The Author(s) 2019

\footnotetext{
${ }^{1}$ KEMRI-Wellcome Trust Research Programme, Bofa Rd, Kilifi - P.O. Box 230 - 80108, Kenya. ${ }^{2}$ Oxford Vaccine Group, University of Oxford, and the NIHR Oxford Biomedical Research Centre, Oxford, Oxford OX3 7LE, UK. ${ }^{3}$ Centre for Tropical Medicine and Global Health, Nuffield Department of Medicine, University of Oxford, OX3 7FZ Oxford, UK. ${ }^{4}$ The Childhood Acute Illness \& Nutrition (CHAIN) Network, Nairobi - P.0. Box 43640-00100, Kenya. ${ }^{5}$ School of Life Sciences and Zeeman Institute (SBIDER), University of Warwick, CV4 7AL Coventry, UK. ${ }^{6}$ These authors contributed equally: Charles J. Sande, James M. Njunge. Correspondence and requests for materials should be addressed to C.J.S. (email: csande@kemri-wellcome.org)
} 